Publikasi

\title{
Penerapan Sistem Penjaminan Mutu Internal di Akper Kesdam I/Bukit Barisan Medan
}

\author{
Muchti Yuda Pratama \\ Ketua Unit Penjaminan Mutu Akper Kesdam I/Bukit Barisan Medan \\ Email: yudamuchti@yahoo.co.id
}

\section{PENDAHULUAN}

Sistem Penjaminan Mutu Internal (SPMI) dipandang sebagai salah satu cara untuk menjawab berbagai permasalahan pendidikan tinggi di Indonesia. Selain itu, SPMI dianggap mampu untuk menjawab tantangan pendidikan tinggi. Secara umum, pengertian penjaminan mutu (quality assurance) pendidikan tinggi adalah proses penetapan dan pemenuhan standar mutu pendidikan secara konsisten dan berkelanjutan sehingga stakeholder memperoleh kepuasan serta proses untuk menjamin agar mutu lulusan sesuai dengan kompetensi yang ditetapkan/dijanjikan sehingga mutu dapat dipertahankan secara konsisten dan ditingkatkan secara berkelanjutan. Dengan kata lain, perguruan tinggi dikatakan bermutu apabila mampu menetapkan dan mewujudkan visinya melalui pelaksanaan misinya (aspek deduktif), serta mampu memenuhi kebutuhan/memuaskan stakeholders (aspek induktif) yaitu kebutuhan masyarakat, dunia kerja dan profesional. Sehingga, perguruan tinggi harus mampu merencanakan, menjalankan dan mengendalikan suatu proses yang menjamin pencapaian mutu. Tujuan penjaminan mutu adalah memelihara dan meningkatkan mutu pendidikan tinggi secara berkelanjutan, yang dijalankan secara internal untuk mewujudkan visi dan misi perguruan tinggi, serta untuk memenuhi kebutuhan stakeholders melalui penyelenggaraan tridharma perguruan tinggi. Hal tersebut dapat dilaksanakan secara internal oleh perguruan tinggi yang bersangkutan, dikontrol dan diaudit melalui kegiatan akreditasi yang dijalankan oleh Badan Akreditasi Nasional (BAN) Perguruan Tinggi atau lembaga lain secara eksternal. Sehingga objektivitas penilaian terhadap pemeliharaan dan peningkatan mutu akademik secara berkelanjutan di suatu perguruan tinggi dapat diwujudkan. Sesuai dengan Undang-Undang No. 20 tahun 2003 yang berkenaan dengan Sistem Pendidikan Nasional semua elemen pendidikan harus terpadu dalam mencapai tujuan pendidikan nasional, dengan mengembangkan kemampuan serta meningkatkan mutu kehidupan dan martabat manusia. Akper Kesdam I/BB Medan merupakan salah satu perguruan tinggi swasta yang ada di Kota Medan Provinsi Sumatera Utara, di bawah bimbingan Kopertis Wilayah I. Akper Kesdam I/Bukit Barisan Medan telah membentuk Unit Penjaminan Mutu pada tahun 2011, namun penerapannya saat itu belum secara maksimal dilakukan. Program studi yang dikelola saat ini yaitu program studi D-III Keperawatan. Seiring dengan perjalanan waktu, unit penjaminan mutu Akper Kesdam I/Bukit Barisan Medan mengalami pasang surut. Oleh karena itu diperlukan revitalisasi. Revitalisasi SPMI Akper Kesdam I/Bukit Barisan Medan diperlukan agar dalam menjalankan dan melaksanakan penjaminan mutu di Akper Kesdam I/Bukit Barisan Medan dapat secara sistematis, konsisten dan berkelanjutan. Pelaksanaan penjaminan mutu tersebut harus mutlak dilakukan agar beberapa aspek penting berikut dapat tercapai. Diantaranya: visi, misi dan tujuan sistematis, konsisten dan berkelanjutan bisa tercapai, kepentingan dan tuntutan para pihak terkait atau pemangku kepentingan (stakeholders) dapat terpenuhi, dan yang terakhir memenuhi dan 
mematuhi standar nasional pendidikan tinggi sesuai dengan ketentuan peraturan dan perundangundangan terkait yang berlaku.

\section{ISI}

Sesuai dengan Peraturan Menteri Pendidikan dan Kebudayaan Republik Indonesia Nomor 50 Tahun 2014 tentang Sistem Penjaminan Mutu, diketahui bahwa mutu pendidikan tinggi adalah bagaimana tingkat kesesuaian antara penyelenggaraan pendidikan tinggi dengan standar pendidikan tinggi yang terdiri atas Standar Nasional Pendidikan Tinggi dan Standar Pendidikan Tinggi yang ditetapkan oleh Perguruan Tinggi. Ukuran keberhasilan dari suatu perguruan tinggi adalah ada pada penerapan Sistem Penjaminan Mutu Internal (SPMI) yang diterapkan pada masing-masing perguruan tinggi. Penerapan SPMI di perguruan tinggi Akper Kesdam I/Bukit Barisan Medan direncanakan sesuai dengan visi yaitu menjadi perguruan tinggi kesehatan yang unggul dan menghasilkan tenaga perawat profesional serta berdaya saing di tingkat Nasional pada tahun 2020, dan misi yang diharapkan adalah 1) Melaksanakan proses pendidikan dan pengajaran melalui pengembangan pada isi, proses, dan penilaian pembelajaran yang sesuai dengan standar nasional pendidikan, 2) Mengadakan kegiatan penelitian guna pengembangan ilmu pengetahuan dan keterampilan di bidang kesehatan, 3) Mengadakan kegiatan pengabdian kepada masyarakat sebagai wujud pelayanan pendidikan secara edukatif dan penerapan ilmu kesehatan tepat guna untuk meningkatkan derajat kesehatan masyarakat, 4) Memperluas jaringan kerjasama dan kemitraan dengan lembaga pendidikan, penelitian, dan pengabdian kepada masyarakat untuk mendukung terlaksananya program akademik, 5) Menyelenggarakan manajemen lembaga pendidikan tinggi berdasarkan asas tata pamong dan tata kelola yang baik. Tujuan Akper Kesdam I/Bukit Barisan Medan yaitu 1) Menghasilkan perawat profesional yang memiliki ilmu pengetahuan, terampil, kreatif, disiplin, unggul dan kompetitif sesuai dengan Kerangka Kualifikasi Nasional Indonesia, 2) Menghasilkan penelitian kesehatan yang kompetitif dan berhasil guna bagi pemecahan masalah di bidang kesehatan dalam rangka pembangunan bangsa, 3) Menghasilkan pengabdian kepada masyarakat yang inovatif, adaptif, dan bermanfaat bagi masyarakat guna meningkatkan derajat kesehatan masyarakat, 4) Menghasilkan kerjasama dengan institusi/lembaga dalam negeri dan luar negeri dalam meningkatkan kapasitas daya saing institusi, dan 5) Menghasilkan pengelolaan tata pamong dan tata kelola yang baik. Hal ini dirasakan bisa menjawab pemikiran tentang mengapa harus ada penerapan sistem penjaminan mutu internal di Akper Kesdam I/Bukit Barisan Medan. Karena, seakan tak menentu jika suatu perguruan tinggi tidak ada elemen yang mengendalikan mutu perguruan tinggi itu sendiri. Quality improvement yang diharapkan tidak akan terwujud karena tidak ada yang mengakomodir. Semua kegiatan harus dimonev, berkaitan dengan mengumpulkan, merencanakan, menyusun, menganalisis dan melaporkan data tentang bagaimana kinerja dari beberapa pelaku atau penggiat pendidikan seperti: dosen, tenaga kependidikan dan semua elemen yang terlibat langsung dengan Akper Kesdam I/BB Medan harus dievaluasi sesuai dengan Manual Prosedur (MP). Penilaian kinerja dosen misalnya, hal ini terus dilakukan dalam rangka mengetahui persepsi mahasiswa bagaimana proses pembelajaran yang telah dilaksanakan, karena tidak ada jaminan bahwa proses pembelajaran yang telah dilakukan di Akper Kesdam I/Bukit Barisan Medan dimana dosen-dosen yang mengajar benar-benar sesuai dengan kurikulum dan Rencana Pembelajaran Semester (RPS) yang telah dibuat. Penyimpangan yang terjadi dalam proses pembelajaran tidak ada yang mendeteksi jika tidak ada sistem penjaminan mutu internal di Akper Kesdam I/Bukit Barisan Medan. Keberadaan unit penjaminan mutu di lingkungan Akper Kesdam I/Bukit Barisan Medan juga berperan dalam menyediakan sarana, prasarana, 
sumber daya yang diharapkan oleh mahasiswa, baik dari segi tata layanan/kependidikan maupun dosen. Penilaian kinerja segala sesuatu hal yang sifatnya untuk mencapai suatu target/sasaran. Berikut merupakan tugas dan tanggung jawab unit penjaminan mutu di Akper Kesdam I/Bukit Barisan Medan yaitu: 1) Merencanakan, menyusun, mengendalikan dan mengawasi kegiatan administrasi bidang penjaminan mutu pendidikan, 2) Merencanakan, menyusun dan mengendalikan kegiatan akreditasi program studi dan akreditasi institusi pendidikan, 3) Merencanakan, menyusun, mengendalikan kegiatan evaluasi standar dosen, 4) Merencanakan, menyusun, dan mengendalikan kegiatan evaluasi proses belajar dan mengajar, 5) Merencanakan, menyusun mengendalikan kegiatan evaluasi pencapaian kompetensi lulusan, 6) Merencanakan, menyusun dan mengendalikan kegiatan penyusunan karya tulis ilmiah mahasiswa, 7) Mengendalikan kegiatan evaluasi bidang penelitian, pengabdian pada masyarakat dan kegiatan layanan kepada mahasiswa, 8) Menyusun perangkat yang diperlukan termasuk dokumen mutu dalam rangka pelaksanaan sistem penjaminan mutu internal, 9) Melaksanakan audit mutu akademik internal dan membuat rencana tindak lanjut terhadap hasil audit internal, 10) Melaporkan secara berkala kepada Direktur terkait dengan pelaksanaan sistem penjaminan mutu akademik internal, dan 11) Berkoordinasi dengan Pudir I, II, III, dan UPPM untuk peningkatan mutu pendidikan. Dalam proses penerapan SPMI di Akper Kesdam I/Bukit Barisan Medan, masih terdapat beberapa hambatan dalam penerapannya, upaya yang dilakukan dalam mengatasi hambatan penerapan SPMI di Akper Kesdam I/Bukit Barisan Medan. Adapun hal yang dilakukan untuk mengatasi hambatan tersebut di atas adalah sebagai berikut: 1) Melakukan sosialisasi tentang komitmen mutu secara berkelanjutan kepada unit-unit, dosen, tenaga kependidikan, dan mahasiswa, 2) Meminta kepada masing-masing unit untuk menetapkan sasaran mutu unit, 3) Meminta kepada masing-masing unit untuk menyusun program kerja yang mengacu kepada pernyataan standar masing-masing standar, 4) Melakukan audit mutu internal secara berkala dan memberikan solusi terhadap masalah yang dijumpai pada saat audit dan juga melibatkan semua pejabat struktural untuk menjadi auditor, 5) Memberikan penghargaan kepada masing-masing unit yang berhasil melakukan pengembangan terhadap standar yang telah tercapai, 6) Memberikan keteladanan, contoh peran dari para pejabat struktural, 7) Menjamin terlaksananya proses kedisiplinan dan tertib adminitrasi bagi sivitas akademika dosen, tenaga kependidikan, dan mahasiswa, 8) Memperkuat dukungan dan menjalin komunikasi yang baik dengan Direktur dan Yayasan, 9) Mengkondisikan iklim keterbukaan di antara manajemen, sivitas, dan karyawan terhadap dinamika perubahan sebagai dampak penerapan penjaminan mutu. Berikut manfaat sistem penjaminan mutu internal yang ada di kampus secara holistik yaitu: 1) melakukan audit mutu internal (SPMI) di program studi, 2) Mengawasi prosedur mutu yang sesuai dengan standar mutu layanan yang telah ditetapkan, 3) Memperbaiki dan mengelola sistem tata layanan perguruan tinggi agar dapat bekerja sesuai standar yang telah ditetapkan, 4) Memeriksa keefektifan pencapaian pembelajaran yang dilakukan oleh tenaga pendidik, 5) Membuat kebijakan akademik, standar akademik, peraturan akademik, standar mutu, manual mutu dan prosedur mutu perguruan tinggi, 6) Memfasilitasi evaluasi kinerja, sistem kontrol dan prosedur penjaminan mutu. Selain itu, penjaminan mutu Akper Kesdam I/Bukit Barisan Medan juga bercita-cita untuk menciptakan anak bangsa agar menjadi orang yang cerdas dan berakhlak mulia. Manfaat sistem penjaminan mutu internal Akper Kesdam I/Bukit Barisan Medan di atas dilaksanakan dengan berpedoman pada prinsip: berorientasi kepada pemangku kepentingan internal dan eksternal, mengutamakan kebenaran, tanggung jawab sosial, pengembangan kompetensi personil, partisipatif dan kolegial, keseragaman metode, inovasi pembelajaran dan perbaikan secara berkelanjutan. Sistem penjaminan mutu internal yang digunakan Akper 
Kesdam I/Bukit Barisan Medan mengacu pada model PPEPP (Penetapan, Pelaksanaan, Evaluasi, Pengendalian dan Peningkatan). Model PPEPP mengharuskan Akper Kesdam I/Bukit Barisan Medan agar secara berkala dapat melakkan proses evaluasi diri dalam menilai kinerja masingmaisng dengan menggunakan standar dan prosedur yang telah ditetapkan, tindakan selanjutnya adalah melaporkan hasil evaluasi diri kepada Ketua Akper Kesdam I/Bukit Barisan Medan. Terhadap hasil evaluasi diri pimpinan unit dan Direktur Akper Kesdam I/Bukit Barisan Medan akan membuat keputusan tentang langkah atau tindakan yang harus dilakukan untuk memperbaiki dan meningkatkan mutu Akper Kesdam I/Bukit Barisan Medan. Keadaan ini diartikan bahwa ada usaha perbaikan atau peningkatan yang disesuaikan dengan hasil evaluasi SPMI dan kebutuhan dari kurikulum pembelajaran, kemahasiswaan, sumberdaya, sarana prasarana, suasana akademik, penelitian dan pengabdian kepada masyarakat.

\section{PENUTUP}

Proses penjaminan mutu seharusnya bukan hanya menjadi tanggung jawab Direktur melainkan menjadi tanggung jawab semua pihak dalam sivitas akademika Akper Kesdam I/Bukit Barisan Medan. Semua komponen seharusnya melakukan tindakan yang benar sesuai standar yang telah ditentukan. Keberhasilan melaksanakan proses penjaminan mutu internal dipengaruhi juga oleh iklim kampus yakni komunikasi dan tim kerja yang harmonis. Melihat tuntutan dan perkembangan ilmu yang semakin kompleks, unit penjaminan mutu Akper Kesdam I/Bukit Barisan Medan terus memperbaiki budaya mutu yang baik dengan mengacu pada model PPEPP. Revitalisasi penerapan SPMI di Akper Kesdam I/Bukit Barisan Medan terus direncanakan sesuai dengan visi dan misi Akper Kesdam I/Bukit Barisan Medan. Semua proses kegiatan yang diselenggarakan oleh Akper Kesdam I/Bukit Barisan Medan selalu dievaluasi untuk menemukan kekuatan dan kelemahan kegiatan tersebut, sehingga dapat dilakukan perubahan ke arah perbaikan secara berkelanjutan. Efek yang paling berpengaruh terhadap penerapan SPMI di Akper Kesdam I/Bukit Barisan Medan adalah meningkatnya akreditasi program studi dimana saat ini Program Studi D-III Keperawatan Akper Kesdam I/Bukit Barisan Medan berhasil naik peringkat dari akreditasi C menjadi akreditasi B di tahun 2017 dan berlaku sampai tahun 2022. Harapan ke depannya adalah penerapan SPMI di Akper Kesdam I/Bukit Barisan Medan dapat terus dilakukan secara sistematis, konsisten dan berkelanjutan agar mutu perguruan tinggi khususnya di Kota Medan dan Propinsi Sumatera Utara menjadi lebih baik dan membanggakan. 